\title{
Microscopical Evaluation of Hard Zinc Refining by Aluminium
}

Jarmila Trpčevská, Blanka Hol'ková, Jana Pirošková, Mária Ferencová

Department of Non-ferrous Metals and Waste Treatment, Faculty of Metallurgy, Technical University of Košice, Letná 9/A, 04200 Košice, Slovak Republic.E-mail: jarmila.trpcevska@tuke.sk

Hot-dip galvanizing is one of the most widely used method for protecting of structural steels against corrosion. In general galvanizing process dross called as „hard zinc“ is formed on the bottom of the zinc bath. It is formed by the reactions between molten zinc and iron particles in the galvanizing kettle. Hard zinc represents valuable secondary raw material because of the high content of metallic zinc (94-97\%). Bottom dross, being an alloy of zinc and intermetallic phase crystals containing 3-6\% wt. Fe, has no direct use in the galvanizing process. For this reason there are attempts to elaborate the technology of obtaining a refined zinc containing less then $0,05 \%$ wt. Fe. Hard zinc refining with aluminium is one of the method for iron removing. Refining process is based on the formation of intermetallic particles of $\mathrm{Al}_{x} \mathrm{Fe}_{\mathrm{y}}$ type. Refining of hard zinc through removal of iron has been investigated in this study. The effect of various aluminium additions as a refining agent has been studied. Light microscopy and AAS (Atomic absorption spectroscopy) have been used in the evaluation of the refining process.

Keywords: Hot-dip galvanizing, hard zinc, refining

\section{Acknowledgement}

This work has been supported by a grant from Slovak National Grant Agency under the VEGA project 1/0235/12.

\section{References}

[1] Maass, P. Peissker, P.: Handbook of Hot-dip Galvanization. Wilez-VCH Verlag GmbH\&Co. KGaA, Weinheim, (2011) pp. 21-90. ISBN978-3-527-32324-1

[2] MARDER, A. R. The Metallurgy of Zinc - coated steel. In Progress in Materials Science, 45 (2000), pp. 191271.

[3] JHA, M. K. et. al: Review of hydrometallurgical recovery of zinc from industrial wastes. In: Resources, Conservation and Recycling, 33 (2001), pp. 1-22.

[4] LIBERSKI, P.: Theoretical and Practical Aspects of Zinc coatings on ferroalloys created by hot dip galvanizing process. In: 14. Conference žárového zinkování. Hrotovice (2008), pp.42-51. ISBN 978-80-254-2679-1

[5] VOURLIAS, G. et. al.: Study of the structure of hot-dip galvanizing byproducts. In: Journal of optoelectronics and advanced materials, 9 (2007), pp. 2937-2942.

[6] VOURLIAS, G. et. al: A negative effects of the insoluble particles of dross on the quality of the galvanized coatings. In: Solid State Sciences, 7 (2005), pp. 465-474.

[7] BRIGHT, M. A. The advantages of recycling metallic zinc from the processing wastes of industrial molten zinc applications. In: TMS Annual Meeting \& Exhibition, Orlando, Florida, 2007, pp.101-109.

[8] KOZLOWSKI, J.; LASKAVIEC. J.: Refining alloy zinc-iron with intermetallic phases $\mathrm{Zn}_{\mathrm{n}} \mathrm{Fe}_{\mathrm{m}}$ by formation phases $\mathrm{Al}_{\mathrm{n}} \mathrm{Fe}_{\mathrm{m}}$. In: Intermetallics, 8 (2000), pp. 1439-1442.

[9] BARAKAT, M. A.: Removal of iron from hard zinc for production of refined zinc. In: The Open Mineral Processing Journal, 2 (2009), pp. 12-16.

[10] SHAHVERDI, H. R., et. al.: Microstructural analysis of interfacial reaction between molten aluminium and solid iron. In: Journal of Materials Processing Technology, 124 (2002), pp. 345-352.

[11] KUFFA, T.; SÚČIK, G.: Spravovanie tvrdých zinkov na ZnO. In Acta Metallurgica Slovaca, 7 (2001), pp. 7982.

[12] MOLNÁR, F.; ČECH, J.: Možnosti prípravy zliatin Zn - Al rafináciou tvrdého zinku hliníkom. In: Acta Metallurgica Slovaca, 1 (2005), pp. 74-77. 